\title{
Patterns of Teaching-Learning Interaction in the EFL Classroom
}

\author{
Fatimah Mulya Sari \\ fatimah@teknokrat.ac.id \\ Universitas Teknokrat Indonesia
}

\begin{abstract}
The successfullness of teaching-learning process is highly influenced by the patterns of interactions appeared in the classroom activities. Through this case study, the purpose of this paper is to explore the patterns of interaction during teaching and learning proccess. Two accellerated classes were observed and recorded to gain the data. The findings revealed that the patterns of interaction emerged in the first class were group work, choral responses, closed-ended teacher questioning (IRF), individual work, student initiates-teacher answers, open-ended teacher questioning, and collaboration. Meanwhile, the patterns of interaction in the second class showed closed-ended teacher questioning (IRF), open-ended teacher questioning, choral responses, student initiates-teacher answers, group work, and individual work pattern. The patterns of interaction were produced from teacher and student(s) and/or student( $(s)$ and student( $(s)$ in relation to the teacher talk and the students talk categories used during learning activities. These patterns were produced constantly. They are to show that the teaching-learning process was not always dominated by the teacher. Most students actively participate as well in any classroom activity. Thus, these patterns absolutely increase the students talk and students' participation in the class. It is necessary for teachers to reorganize the active activities which might foster more interaction in the classroom.
\end{abstract}

Key Words: EFL Classroom, patterns of interaction, teaching-learning process.

\section{Introduction}

Interaction in the classroom plays pivotal roles. These emerge as a great solution for creating successful interactive systems and interaction design in teaching and learning process. Teacher and students share and receive messages to achieve communicative process since it is reciprocal effect requiring teacher and students to exchange the thoughts and feelings (Brown, 2000; Wagner, 1994). This interaction process covers verbal and nonverbal action to promote learning in the classroom. Applying the right patterns of interaction is a fundamental factor in the success of any activity and the achievement of aims. In the classroom, different interaction patterns may support the aims of different kinds of activities such as pair work (a student with a student) and group work (students with students). Changing interaction patterns helps vary the pace, while choosing a right pattern help achieve learning aims and learning productivity.

Analyzing the patterns of interaction has been a research interest leading to a major direction in educational research. Numerous studeis on this area have been aiming at revealing the complexity of foreign language classroom interaction. The study from Rashidi \& Rafieerad (2010) claimed that the patterns of interaction between the participants change by producing a variety of discourse acts, including an IRF patterns in student-teacher talk. It, further, showed that male students were more willing to interact with their teachers than female students. The findings also revealed that the high portion of teachers' domination in classroom talk did not affect students to initiate exchanges with their teachers and give follow-up toward their teachers' responses.

The terms of interaction patterns applied in this study cover all patterns of teaching-learning interaction, including the sequence of active activities used by teachers and students when the knowledge or teaching material is being transmitted.

\section{Method}

This case study was conducted in one of top senior high school in Surakarta. These study used two accelerated classes, consisting of fifty two students. The data were taken from non-participant observation, interview, and video-recording.

After collecting the data, they were categorized into some patterns. In this study, the patterns of interaction used were from Ur (1996). The patterns were: (1) group work; (2) closed-ended teacher questioning (IRF); (3) individual work; (4) choral responses; (5) collaboration; (6) student initiates, teacher answers; (7) full-class 
interaction; (8) teacher talk; (9) self-access; and (10) open-ended teacher questioning. The explanation is in the following table:

\begin{tabular}{c|l|l}
\hline No & Patterns of Interaction & \multicolumn{1}{c}{ Definitions } \\
\hline 1 & Group work & $\begin{array}{l}\text { Students work in small groups on tasks that entail interaction: conveying } \\
\text { information, for example, or group decision-making. The teacher walks } \\
\text { around listening, intervenes little if at all. }\end{array}$ \\
\hline 2 & $\begin{array}{l}\text { Closed-ended teacher } \\
\text { questioning (IRF) }\end{array}$ & $\begin{array}{l}\text { Only one 'right' response gets approved. Sometimes cynically called the } \\
\text { 'Guess what the teacher wants you to say' game. }\end{array}$ \\
\hline 3 & Individual work & $\begin{array}{l}\text { The teacher gives a task or set of tasks, and students work on them } \\
\text { independently; the teacher walks around monitoring and assisting where } \\
\text { necessary. }\end{array}$ \\
\hline 4 & Choral responses & $\begin{array}{l}\text { The teacher gives a model, which is repeated by all the class in chorus; or gives } \\
\text { a cue, which is responded to in chorus. }\end{array}$ \\
\hline 6 & Collaboration & $\begin{array}{l}\text { Students do the same sort of tasks as in 'Individual work,' but work together, } \\
\text { usually in pairs, to try to achieve the best results they can. The teacher may or } \\
\text { may not intervene. (Note that this is different from 'Group work, where the } \\
\text { task itself necessitates interaction.) }\end{array}$ \\
\hline 7 & Full-class interaction & $\begin{array}{l}\text { For example, in a guessing game: the students think of questions and the } \\
\text { teacher responds; but the teacher decides who asks. }\end{array}$ \\
\hline 8 & Teacher talk & $\begin{array}{l}\text { The students debate a topic or do a language task as a class; the teacher may } \\
\text { intervene occasionally, to stimulate participation or to monitor. }\end{array}$ \\
\hline 9 & Self-access & $\begin{array}{l}\text { This may involve some kind of silent student response, such as writing from } \\
\text { dictation, but there is no initiative on the part of the student. }\end{array}$ \\
\hline 10 & $\begin{array}{l}\text { Open-ended teacher } \\
\text { questioning }\end{array}$ & $\begin{array}{l}\text { Students choose their own learning tasks, and work autonomously. } \\
\text { There are a number of possible 'right' answers, so that more students answer } \\
\text { each cue. }\end{array}$ \\
\hline
\end{tabular}

\section{Discussion}

This section discusses the findings of teaching-learning interaction patterns in the classroom. In the first class, the teacher (T1) delivered the teaching material of expressing intention and descriptive text about the tourism. The patterns of interaction shaped the patterns of group work, choral responses, closed-ended teachers questioning (IRF), individual work, open-ended teacher questioning, collaboration, and student initiates-teacher answers. The T1 frequently gave directions and asked question. Although the class was still dominated by the teacher, it did not mean that the students were passive. The students seemed to be active since T1 sometimes used interactive and communicative activities such as game, exercises, and discussion to raise the students' interaction and participation. These activities might be done individually, in pairs, or even in groups. These activities also referred to the studentcentered because the students were forced to get involved actively.

First, choral responses pattern occurred when T1 greeted the students by saying 'morning class!' and the students responded with 'morning'. The choral responses pattern occurred, for example, when T1 asked the students about what they wanted to be in the future. The following excerpts are one of the examples of choral responses pattern:

T1 I just want to know who wants to be mmm football player?

Ss No!

T1 No one. The manager of football player?

Ss $\quad$ No one. (Laughing)

Next, when T1 played a short video about Thailand movie, choral responses pattern also occurred when T1 paused the video for a while and asked question about the movie watched. The other choral responses pattern occurred when $\mathrm{T} 1$ asked the students whether they had finished their work. The following excerpts are another example of choral responses pattern:

T1 OK, can you guess who is beggar? Who is the beggar?

Ss A child.

T1 OK, a child. Really?

Ysp Maybe. 


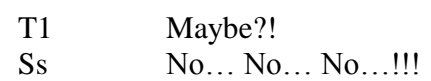

Secondly, closed-ended teacher questioning (IRF) pattern occurred when T1 gave some reflections on the short movie that they watched. This pattern showed how the teacher initiated to ask a question; the students gave response to the teacher's question; and the teacher gave feedback. The following excerpt is one of the examples of this pattern:

T1 ... I just want to know your opinion when the man, the bakmi, the soup seller-soup seller, gives the soup and then gives the money to the boy, OK, can you-can you imagine that he wants to ask the return? Minta balas budi, balas jasa itu ada engga?

Ss $\quad$ No...!

T1 But actually, the good things-the good thing that is done today, maybe we don't get it for the near tomorrow but maybe in the-in the long time. OK. So, from this ... we can learn that we do it in good intention, OK, good intention, we will have the return in the good things too. Ya? Kalau kita berikan sesuatu yang baik dengan yang tidak baik maka akan-akan kembali balasannya itu yang baik.

The third is collaboration pattern. It occurred when T1 gave the students a warmer activity like a game. In the expressing intention material, the students had to do a warmer activity to discuss the picture of four interesting places with their friend. From the warmer activity, T1 asked the students to describe all the pictures and choose one of their favorite places and give the reason. He chose the student's pair or partner by himself. He also gave time-limited for them to do this warmer activity in for about ten minutes and he asked them to deliver their work in front of the class after finishing it. In this activity, the students looked serious to accomplish their task. They once asked to the teacher about something that they did not understand yet. T1 walked around the class for monitoring and assisting when necessary. When time was up, T1 called some pairs to come in front of the class to read their work in turn. This is one of the excerpts of collaboration pattern:

Esw Good morning, ladies and gentlemen. We are from the third emm the third team will describe all the pictures.

Fgw For the first, I think people visit beach because at beach we can see scener---scenery freely. We can surf, swim, play some games of water, build sands castle for children, sunbath, and enjoy the sunset view. And the second called amusement park, I think people visit it because they can forget all their problems and enjoy games. In there, people can play a lot of extreme games, enjoy walking time, and jogging in the morning.

T1 Good! next!

Esw So, emm we go to the mall and mountain. Emm first, we go to the mall. Why people like visit the mall because it is cool-cool place so it is comfortable. It is a clean and many shops in there. Because many shops in there so we can-we can doing shopping or exercising in there. And then we go to the mountain. People like vis-visiting mountain because it is emm there is beauty-beautiful scenery. Emm beautiful scenery so we-we can take a photo and there is a cool place. The place is cool and there is many trees and we can see many beautiful flowers. In there, we can do take a photo, climbing, and camping. So in here, we-we prefer amusement park. We, the reason is in amuse--amusement park we can doing free.

The last pattern is student initiates-teacher answers. This pattern occurred when the student thought for questions and initiated to ask it to the teacher directly and then teacher gave response and feedback to answer student's question. The following excerpts are the example of this pattern:

$\begin{array}{ll}\text { Esw } & \text { Describe all or ... } ? \\ \text { T1 } & \text { You describe all. } \\ \ldots & \\ \text { Esp } & \text { Wahana permainan apa, pak? Wahana permainan? } \\ \text { T1 } & \text { Play zone. } \\ \ldots & \\ \text { Ew } & \text { Ini kelompok Pak? Kelompok atau individual? } \\ \text { T1 } & \text { Your previous pair. }\end{array}$


In the second observation, the material used by $\mathrm{T} 1$ was 'descriptive text about the tourism'. The patterns of interaction occurred are group work, choral responses, closed-ended teacher questioning (IRF), individual work, student initiates-teacher answers, and open-ended teacher questioning.

First of all, the pattern of group work occurred when T1 gave a game of 'draw and guess' to his students. This is a kind of warmer activity. In this activity, T1 divided the students into two big groups. Each group consisted of ten students. Each group had a leader to choose two representatives as the drawer in the whiteboard in the front of the class. Then, T1 gave explanation about the rules of game and how it works. Each group cooperatively got involved in this game. They were excitedly playing the game in groups.

The second is choral responses pattern. This pattern occurred when $\mathrm{T} 1$ gave pronunciation practice to his students and asked about the sentence which consisted of passive voice. Here, T1 directed them to repeat the word what he had pronounced.

T1 And then, I'd like you to go on page eighty-three. Listen to me and then after that repeat after me!

T1 Niagara.

Ss Niagara.

T1 Once again, Niagara.

Ss Niagara.

T1 Gorge.

Ss $\quad$ Gorge.

T1 Gorge.

Ss $\quad$ Gorge.

The third is closed-ended teacher questioning (IRF) pattern. Like in the first observation, the pattern of closed-ended teacher questioning (IRF) also occurred in the second observation. The excerpt of closed-ended teacher questioning (IRF):

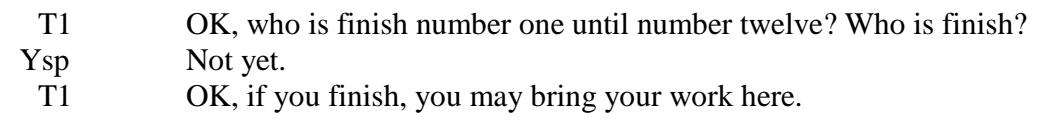

The next pattern is individual pattern. In the individual pattern, the students were asked to do vocabulary builder exercise and match the pictures with paragraphs. Here, their task was to complete the missing letters of the English words and match the paragraphs of visiting Niagara Falls' text with pictures provided. The students had to do this exercise by themselves. While the students did their work, T1 walked around for checking their progress in doing it. After the students finished their task, they discussed the answer together to check their work. This is one of the excerpts of individual work from their book:

The next pattern is student initiates-teacher answers. The students asked the question related to the material or activity that they did and the teacher responded to it by giving feedback. The following is one of the excerpts of student initiates-teacher answers pattern:

N1 Pak, pak, pak, tanya kalo misalnya sebelum selesai pak, terus udah...

(Her word was cut by teacher because the teacher got the point from her question.)

T1 Okay, you raise! (Raising the paper which contains of answer)

The last pattern which comes up in teaching and learning process is open-ended teacher questioning. Here, open-ended teacher questioning occurred when there were a number of possible answers, so more students gave their answer. The excerpt of open-ended teacher questioning can be seen as follows:

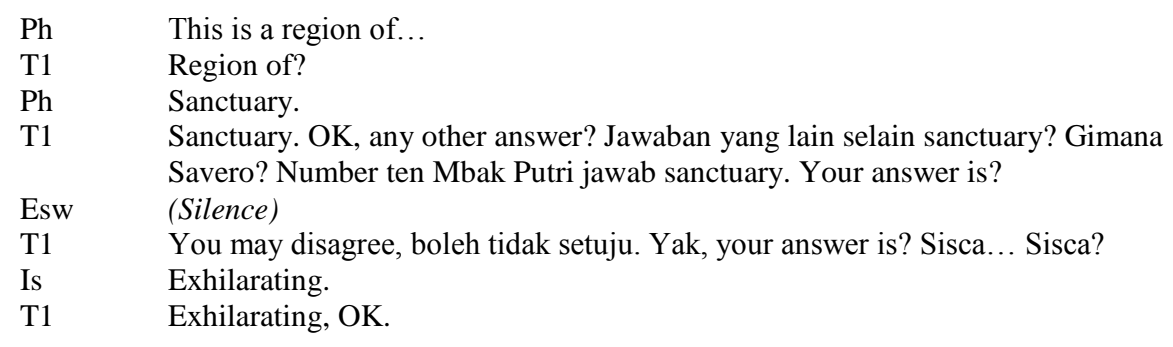


From two observations in the first class, the patterns of interaction emerged during teaching and learning process were almost the same. $\mathrm{T} 1$ always gave learning activity which could increase student awareness to actively talk in the classroom. T1 sometimes asked question which made students answered chorally, answered with different ideas, and so forth. The patterns of interaction occurred in the first observation were choral responses, closed-ended teacher questioning (IRF), collaboration, and student initiates-teacher answers. Meanwhile, the patterns of interaction in the second observation were group work, choral responses, closed-ended teacher questioning (IRF), individual work, student initiates-teacher answers, and open-ended teacher questioning. In short, the patterns of interaction which emerge from the first class were group work, choral responses, closed-ended teacher questioning (IRF), individual work, student initiates-teacher answers, open-ended teacher questioning, and collaboration.

In the second class, the teacher (T2) delivered the teaching material of describing people and describing places. The patterns of interaction occurred are closed-ended teacher questioning (IRF), open-ended teacher questioning, choral responses, student initiates-teacher answers, group work, and individual work pattern. The T2 mostly performed asking questions, lecturing or giving information, and giving directions during teaching and learning process. In other side, the students are also active although the teacher dominates the classroom. It happens since T2 provides game, exercises from the English book of 2013 curriculum and other sources, and discussion to raise the students' participation and interaction. T2 also gives students such an activity which has to be accomplished by individual, pairs, or even group.

The first pattern is closed-ended teacher questioning (IRF). This pattern occurred when T2 asked a question; the student responded it; and the teacher gave the feedback. The following excerpt is one of the example of this pattern:
$\mathrm{T} 2$
$\mathrm{S}$
Do not say hair is banyak. Hair is? Can you count it one by one?
$\mathrm{T} 2$
Uncountable.
Good. So hair is uncountable.

The second pattern is open-ended teacher questioning. Like in the first class, open-ended teacher questioning here occurred when there were a number of possible answers, so more students gave their answer. This is one of the excerpts of open-ended teacher questioning:

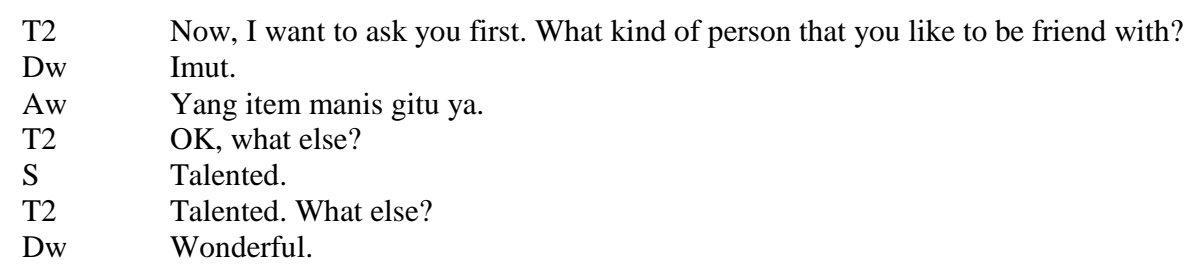

The next pattern is choral responses. It occurred when T2 asked a general question so that the students knew the answer and said it chorally. The choral responses also occurred when the teacher asked the information given after they listened to the information. This is the excerpts of this pattern:

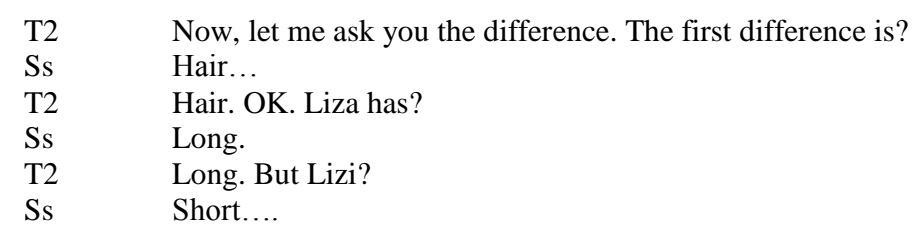

The student initiates-teacher answers pattern also occurs in the second class when student is curious about something then asks it further to teacher without teacher's command. The excerpt of this pattern is:

$\begin{array}{ll}\text { T2 } & \text { We call it complexion. } \\ \mathrm{S} & \text { What is that? } \\ \mathrm{T} 2 & \text { The color of your skin. }\end{array}$

The next pattern is group work. The group work pattern occurred when T2 provided the students with a group task to describe picture of people. T2 divided the students into three groups. They worked with their group with the supervision from the teacher who walked around the class. The individual work pattern is the last pattern 
which emerges in the first observation. In individual work, T2 gave the students a task in a piece of paper given by her. They had to distinguish the changes of person from physical appearance and draw the face of that person. And then, the second is listening exercise. T2 asked them to write down the information that they heard from the descriptions of three important people.

Furthermore, in the second observation, the material used by T2 was 'describing places'. The patterns of interaction occurred are choral responses, open-ended teacher questioning, individual work, student initiatesteacher answers, and closed-ended teacher questioning (IRF). All of these patterns emerge in the first observation.

The first is the choral responses. This pattern occurred when T2 greeted the students in the beginning of lesson and the students greeted back to the teacher. It also occurred when T2 asked the student to describe their classroom and directed them to repeat the words that she had pronounced. The following is one of the excerpts of this pattern:

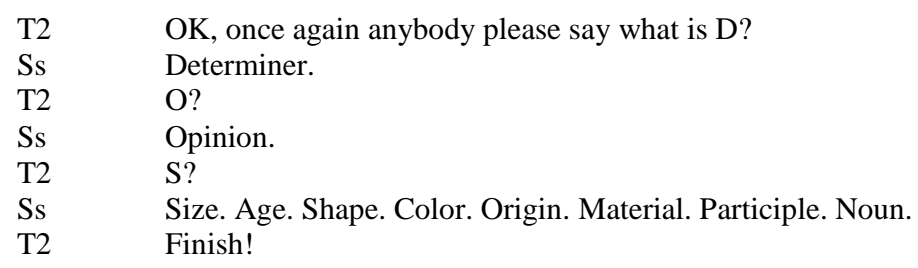

The second pattern is open-ended teacher questioning. This pattern occurred when the teacher asked general question and there were more students who answered the possible right answer. The excerpt is as follows:

$\begin{array}{ll}\text { T2 } & \text { How do you feel when you are in this classroom? } \\ \text { Rha } & \text { Happy. } \\ \text { Dw } & \text { Hot. } \\ \text { Sn } & \text { Cold. } \\ \text { T2 } & \text { Cold. Hot. The two persons have the same idea. }\end{array}$

The third pattern is individual work. In one occasion, this pattern occurred when T2 wrote four sentences in the whiteboard after explaining the grammar about the order of adjectives before a noun. Then, she asked the students to do it independently. After that, she called four students to write their answer in the whiteboard. Next, $\mathrm{T} 2$ also gave exercises from other sources about participles. The students did it individually. The next pattern is student initiates-teacher answers. The student initiates to ask a question then teacher answer and explain about student's question. This is the excerpt of this pattern:

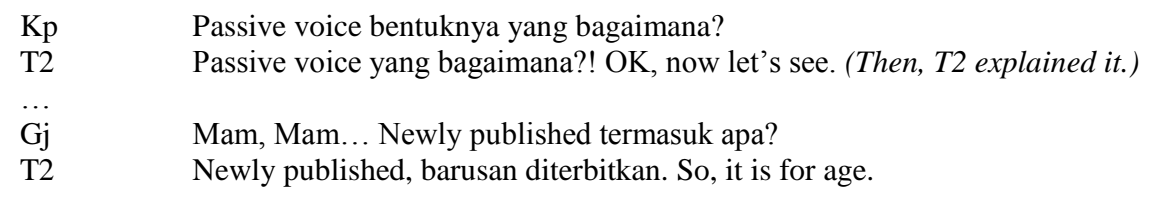

The last pattern is closed-ended teacher questioning (IRF). This pattern showed how the teacher gave a question to the students; the students respond it; and the teacher gave the feedback. The following excerpt is one of the examples of this pattern:

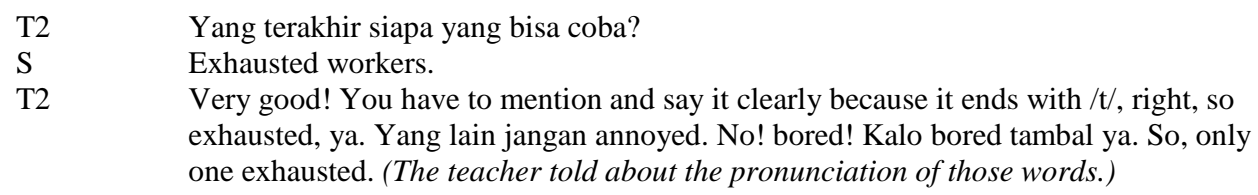

The patterns of interaction which occurred in the first observation were closed-ended teacher questioning (IRF), open-ended teacher questioning, choral responses, student initiates-teacher answers, group work, and individual work pattern. Meanwhile, the patterns of interaction in the second observation are choral responses, open-ended teacher questioning, individual work, student initiates-teacher answers, and closed-ended teacher questioning (IRF). In short, it can be stated that the patterns of interaction in the second class of the tenth grade are closed-ended teacher questioning (IRF), open-ended teacher questioning, choral responses, student initiates-teacher answers, group work, and individual work pattern. 
The research findings show that the patterns of interaction during teaching and learning process emerged from the first class and the second class were not fully dominated by the teacher because the students also actively participated in teaching and learning process. Two teachers emphasized on the student-centered, relying heavily on hands-on activities, group work, peer work, individual work, projects, and discussion to engage students and encourage active participation. The patterns of interaction during teaching and learning process in this research occur between teacher and student or student and student. These result is similar to Brown's (2000: 165) statement which is that interaction is the collaborative exchange of thoughts, feelings, or ideas between two or more people, resulting in a reciprocal effect on each other. The term of interaction implies an action-reaction or a two-way influence which may be between individuals (e.g. student-student or teacher-student) or between an individual and a group (e.g. teacher-audience) or between materials and individuals (Biddle, 1967, cited in Sadeghi et al., 2012: 167).

Based on the data, there are seven patterns of interaction which come up in the first class are the patterns are group work, choral responses, closed-ended teacher questioning (IRF), individual work, student initiatesteacher answers, open-ended teacher questioning, and collaboration. On the other side, the collaboration pattern is the only pattern which never emerges in the second class. So, the second class has six patterns of interaction are group work, choral responses, closed-ended teacher questioning (IRF), individual work, student initiates-teacher answers, and open-ended teacher questioning.

Firstly, a learner-centered activity such as group work, which forces students to talk to each other spontaneously, ask each other questions, and respond in a natural way, is one of example how this might be practiced. In group work pattern, the students are given a group task in doing learning activities like playing game and doing a task from the book. To support it, Meng and Wang (2011:102) assert that group work activity is a good way to change the traditional teacher talk that dominates the class. Besides, Jones (2007: 3) states that when students are working together in English, they talk more, share their ideas, learn from each other, get involved more, feel more secure and less anxious, and enjoy using English to communicate. It is in line with Lightbown and Spada (1999: 85) who argue that students produce not only a greater quantity but also a greater variety of language functions, for example, disagreeing, hypothesizing, requesting, clarifying, and defining. Bentley (2007: 133) also notes that assigning roles to group members can help students learn to take responsibility for managing and evaluating what happens during the task and also promote positive group dynamics. The potential advantages of group work are also strengthened by Ur (1996: 232) who mentions that group work has advantages such as fostering learner responsibility and independence, improving motivation, and contributing to a feeling of cooperation and warmth in the class.

The second pattern of interaction is choral responses. The choral response occurred when the teachers gave pronunciation practice to the students and asked a general question so that all students can guess the right answer and say it chorally. In pronunciation practice, the teacher asks them to hear it first and then repeat to pronounce it in a chorus at the same time. In general, choral responses from the students are common in English lesson. The choral answers are responses to teacher's statements, questions, or directions. The students use choral responses as a means of assuring the teacher that they understand the lesson given. The negative side of choral responses, however, is that some students may go with the flow and the teacher may think that every student has understood the lesson material. Thus, it is supported with Brock-Utne (2006: 35). He says that chorus answer refers to the safe talk for both the teacher and the learners, in that the teacher accepts the answers without finding out whether every learner understands the lesson.

The next pattern is closed-ended teacher questioning (IRF). Closed-ended teacher questioning (IRF) pattern shows how the teacher initiates to ask a question, students give response to teacher's question, and teacher gives feedback. The IRF is often seen as encouraging students to respond only with an evaluable answer. In this pattern of interaction, the teachers always initiate questions and the students are expected to respond only to the questions given to them. The teacher is the only active participant, while the students remain passive recipients of knowledge (Martin et al., 1994: 49). In addition, Ur (1996: 239) suggested that closed-ended teacher questioning (IRF) is the usual solution.

Another pattern is individual work. This pattern occurred; for example, when the teacher asked the students to do the exercise from the book. The students have to do this exercise by themselves. The next is student initiatesteacher answers. The pattern occurred when the students were curious about the lesson or something else and asked it further to the teacher without teacher's command and then teacher gives response to answer student's question. The other pattern is open-ended teacher questioning. The teacher asks a question in which there are a number of the possible right answers. 
The last pattern is collaboration. The collaboration pattern is also well-known as pair work pattern. It occurred when the students work in pair to do the activity or task given by the teacher. The activity that is used by the teachers is in line with what Watcyn-Jones (2002: 7) mentions. He mentioned that there are several types of activities for working in pairs such as ice-breaker or warm-up activities. Wallace, Stariba, and Walberg (2004: 14) note that frequent collaboration gives chances to the students in communicating meaningful ideas one another and being active learners. To strengthen it, Storch (2001: 53) argues that collaboration pattern seems to be a good idea for teachers to give a communicative activities because it immediately develops the amount of student practice. In short, collaborative work often exerts a beneficial effect on task performance.

In conclusion, the learning activities used by the teachers might emerge some patterns of interaction. The teacher should consider in developing and increasing those patterns in their classroom. By using game, exercises, and discussion, they might raise the students' interaction and participation or increase student awareness to actively talk in the classroom. The learning activities should be done with variation way by using interesting material from English handbook or other sources.

\section{Conclusion}

It can be concluded that the patterns of teaching-learning interaction appear variously and constantly. These patterns show that the process of teaching and learning is not always dominated by the teachers. It clearly shows that the students engaged in any classroom activity. The patterns of interaction absolutely enhance the students talk and participation in the class.

The interaction patterns of group work, choral responses, closed-ended teacher questioning (IRF), individual work, student initiates-teacher answers, open-ended teacher questioning, and collaboration appear in the class when the teachers apply communicative learning activities such as drills, crack the case, and games. In short, these patterns of teaching-learning interaction emerge among teacher and student(s) and/or student(s) and student(s) in relation to the teacher talk and the students talk categories used during classroom activities.

\section{References}

Bentley, K. 2007. STT: Student Talking Time. How Can Teachers Develop Learners' Communication Skills in a Secondary School CLIL Programme? Volumen Monografico, 129-139.

Brock-Utne, B. 2006. Learning through a Familiar Language versus Learning through a Foreign Language-a Look at Some Secondary School Classrooms in Tanzania. In: Brook-utne, B., Z Desai, \& M. Qorro (Eds). Focus on Fresh Data on the Language of Instruction Debate in Tanzania and South Africa. Cape Town: African Minds, 19-40.

Brown, H. D. 2000. Teaching by Principles: An Interactive Approach to Language Pedagogy (2 ${ }^{\text {nd }}$ Edition). New York: Pearson Education.

Jones, L. 2007. The Student-Centered Classroom. Cambridge: Cambridge University Press.

Lightbown, P. \& Spada, N. 1999. How Languages are learned. Cambridge: Cambridge University Press.

Meng, X. \& Wang, X. 2011. Action Study of Teacher's Language on EFL Classroom Interaction. Theory and Practice in Language Studies, 1(1), 98-104.

Rashidi, N. \& Rafieerad, M. 2010. Analyzing Patterns of Classroom Interaction in EFL Classrooms in Iran. The Journal of ASIA TEFL, 7(3), 93-120.

Sadeghi, S., Ketabi, S., Tavakoli, M., \& Sadeghi, M. 2012. Application of Critical Classroom Discourse Analysis (CCDA) in Analyzing Classroom Interaction. English Language Teaching, 5(1), 166-173).

Storch, N. 2001. How Collaborative is Pair Work? ESL Tertiary Students Composing in Pairs. Language Teaching Research, 5, 29-53.

Ur, P. 1996. A Course in Language Teaching: Practice and Theory. Cambridge: Cambridge University Press.

Wallace, T., Stariba, W.E., and Walberg, H.J. 2004. Teaching Speaking, Listening, and Writing. Brussels: International Academy of Education.

Watcyn-Jones, P. 2002. Pair Work 2. Penguin Books. 